\title{
Ecological Perspectives of Land Use History: The Arid Lands Ecology (ALE) Reserve
}

\author{
N. R. Hinds \\ L. E. Rogers
}

July 1991

Prepared for the U.S. Department of Energy under Contract DE-AC06-76RLO 1830

Pacific Northwest Laboratory Operated for the U.S. Department of Energy by Battelle Memorial Instituse 


\title{
DISCLAIMER
}

This report was prepared as an account of work sponsored by an agency of the United States Government. Neither the United States Government nor any agency thereof, nor Battelle Memorial Institute, nor any of their employees, makes any warranty, expressed or implied, or assumes any legal liability or responsibility for the accuracy, completeness, or usefulness of any information, apparatus, product, or process disclosed, or represents that its use would not infringe privately owned rights. Reference herein to any specific commercial product, process, or service by trade name, trademark, manufaclurer, or otherwise does not necessarily constitute or imply its endorsement, recommendation, or favoring by the United States Government or any agency thereof, or Baltelle Memorial Institute. The views and opinions of authors expressed herein do not necessarily state or reflect those of the United States Government or any agency thereot.

\author{
PACIFIC NORTHWEST LABORATORY \\ operated by \\ BATTELLE MEMORIAL INSTITUTE \\ for the \\ UNITED STATES DEPARTMENT OF ENERGY \\ under Contract DE-ACO6-76RLO 1830
}

Printed in the United States of America

Available to DOE and DOE contractors from the

Office of Scientific and Technical Information, P.O. Box 62, Oak Ridge, TN 37831;

prices availatle from (615) 576-8401. FTS 626-8401.

Available to the puhlic from the National Technical Iniormation Service, U.S. Department of Commerce, 52uS Port Royal Rd., Springfield, VA 22161. 
PNL-7750

UC-702

ECOLOGICAL PERSPECTIVES OF LAND USE HISTORY: THE ARID

LANDS ECOLOGY (ALE) RESERVE

\author{
N. R. Hinds \\ L. E. Rogers
}

July 1991

Prepared for the U.S. Department of Energy under Contract DE-AC06-76RLO 1830

Pacific Northwest Laboratory Richland, Washington 99352 
. 


\section{SUMMARY}

The objective of this study was to gather information on the land use history of the Arid Land Ecology (ALE) Reserve so that current ecological research could be placed within a historical perspective. The data were gathered in the early 1980 s by interviewing former users of the land and from previously published research (where available).

Interviews with former land users of the ALE Reserve in Benton County, Washington, revealed that major land uses from about 1880 to 1940 were homesteading, grazing, oil/gas production, and road building. Land use practices associated with grazing and homesteading have left the greatest impact on the landscape. Disturbed sites where succession is characterized by non-native species, plots where sagebrush was railed away, and sheep trails are major indications today of past land uses. Recent estimates of annual bunchgrass production on ALE do not support the widespread belief that bunchgrasses were more productive during the homesteading era, though the invasion of cheatgrass (Bromus tectorum), Jim Hill mustard (Sisymbrium altissium), and other European alien plant species has altered pre-settlement succession patterns. 



\section{ACKNOWLEDGMENTS}

The following persons were interviewed regarding land use history on the ALE Reserve:

Henry, Elmer and Ike Anderson - Local wheat ranchers, pioneers of the area and neighbors of the ALE Reserve.

Malcolm Kerr - Former shepherd for Ben Coffee Sheep Company, former grazers on the ALE Reserve.

Frank Bennett - Pioneer homesteader at Bennett Springs, 1899.

Wayne Stone - Former gas works employee.

Dorothy and Delmer Bronkhorst - Residents of Benson Ranch, 1927-1937.

Dick McWhorter - Local rancher and former user of ALE as a winter grazing territory.

Frank Hamilton. Local wheat rancher and former employee on the Snively Ranch, 1939.

Duane Jacques helped interview local residents and served as a source of ideas and encouragement. Ken Gano assisted with field reconnaissance. Ted Hinds and Bill Rickard reviewed the manuscript and provided ideas and guidance for the study. 


\section{CONTENTS}

SUMMARY

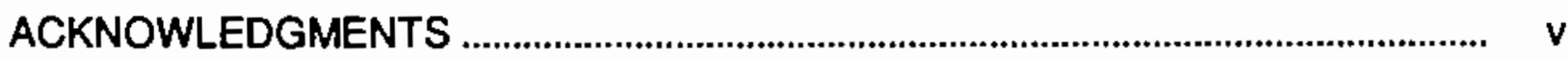

INTRODUCTION ...................................................................................................... 1

THE SETTING: SHRUB-STEPPE LAND IN BENTON COUNTY,

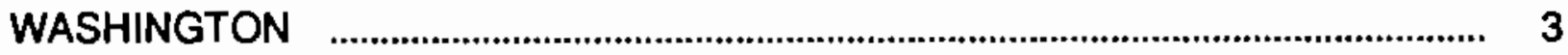

PRE-SETTLEMENT LAND USE ............................................................... 4

HOMESTEADING .................................................................................. 5

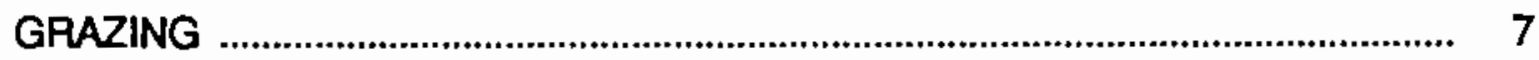

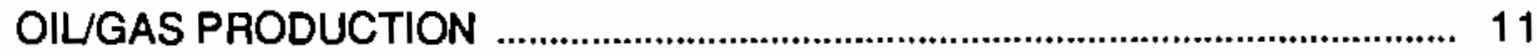

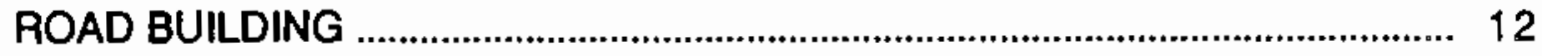

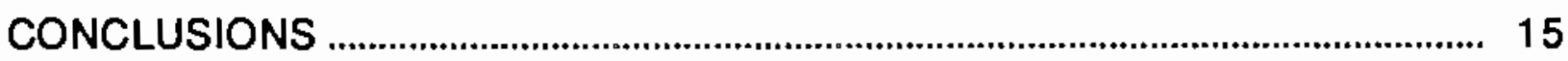

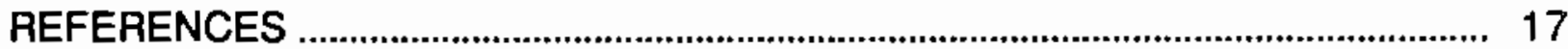





\section{EIGURES}

1 Location of the Arid Land Ecology Laboratory, Washington .......................... 2

2 Plant Communities of the ALE Reserve …....................................................... 5

3 Settlement on the ALE Reserve .........................................................................

$4 \quad$ Porter-Hartman Homestead Circa 1906 ............................................................... 8

$5 \quad$ Grazing Territories on ALE 1880-1940 ...................................................... 10

6 Development of Gas Field on the ALE Reserve, 1929-1941 ........................ 12

\section{TABLES}

1 A Summary of Land Use Practices Employed on the ALE Reserve, 1890-1940 



\section{INTRODUCTION}

In 1967 the U.S. Atomic Energy Commission set aside 120 square miles of shrub-steppe land in southcentral Washington (Figure 1) to preserve "portions of vegetation types that once covered a great expanse of the West" (O'Farrell 1973). This acreage, now known as the Arid Lands Ecology (ALE) Laboratory, (a) serves as a natural research area where scientists can study the shrub-steppe without humanrelated land use pressures.

Until recently, little history of ALE before government acquisition of the land in 1942 had been documented, although some things, such as a few homestead sites and associated abandoned agricultural fields, were known. Relics and artifacts from gas wells and associated structures also marked some areas. It was also known that the area had been grazed by livestock; ecologists presumed the grazing pressure was light, because extensive "mature" stands of big sagebrush (Artemisia tridentata) and bunchgrass (Agropyron spicatum) covered the hillside, water for grazing was sparse, and crustose lichen-moss layer typical of undisturbed soil surfaces in this region was largely intact over most of the area (Pacific Northwest Laboratory 1973).

This study was undertaken to provide background and history for the ALE Reserve before 1940 and to place current ecological research on ALE within a historical perspective. Some current vegetation patterns, for example, can be readily explained by past practices. Knowing something about past land use in an area isolated for more than 40 years should yield insight into how, and how fast, the shrubsteppe responds to and recovers from specific disturbances. Such knowledge may also suggest appropriate research for determining useful relationships among habitat, use, and rate of recovery.

The data gathered during this research came from published documentation and interviews with persons who were former users of land on ALE or close neighbors. Some people generously provided photographs to document structures and verify land use practices.

(a) The ALE Reserve is managed by Pacific Northwest Laboratory for the U.S. Department of Energy. 


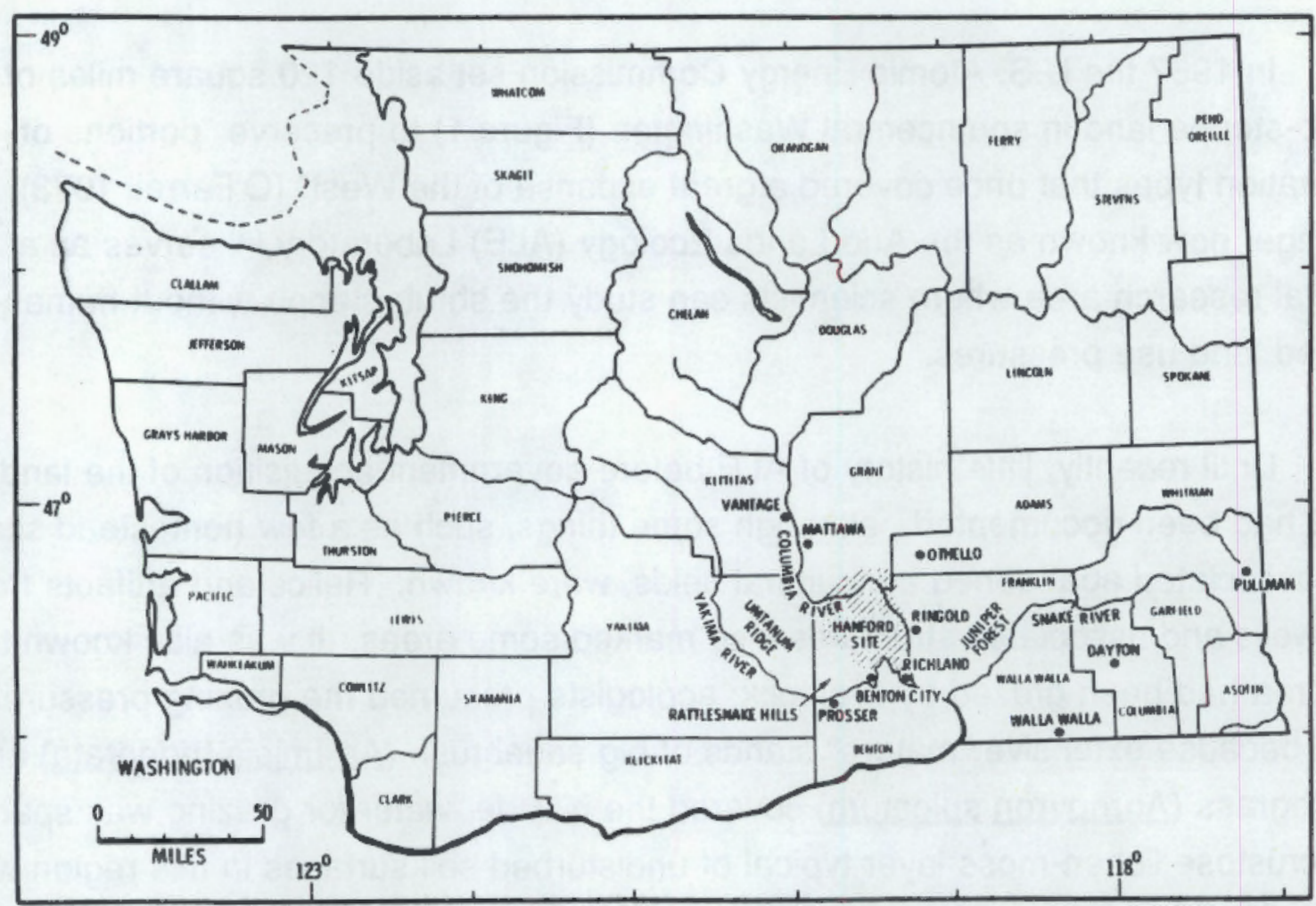

FIGURE 1. Location of the Study Area 


\section{IHE SETTING: SHRUB-STEPPE LAND IN BENTON COUNTY, WASHINGTON}

Arid steppe occupies more than six million hectares (24,000 square miles) of land in central Washington State. The lower Columbia Basin lies deep in the rain shadow of the Cascade Mountains and annually receives only $10-25 \mathrm{~cm}$ of precipitation. Two-thirds of this precipitation occurs during the winter months, about half as snow (Thorp and Hinds 1977; Rotenberry et al. 1976). Warm to hot summers and cool winters are characteristic, with temperatures averaging $25^{\circ} \mathrm{C}$ in July and $0^{\circ}$ $C$ in January.

Settlement in this region took place relatively late. The first recorded immigration into the country occurred in 1853 , when the Longmire party left the Oregon trail at Pendleton, Oregon, and turned north to pass through the Yakima Valley. A description of their tour across what is now the ALE Reserve provides a glimpse of what early settlers (and later historians) thought of the area:

At the Horn, a place where the Yakima River makes a sharp bend at the point of a mountain, they turned north and camped at a place later known as the E.F. Benson ranch just below Rattlesnake Springs....It was a desolate region. It is today. There are miles and miles of sagebrush inhabited only by coyotes and rattlesnakes, while eagles sail far up in the blue.(a)

Cattle were introduced into the Yakima Valley around 1860 (Meinig 1968) and soon became the mainstay of the area's economy. With the completion of the Northern Pacific Railroad in 1870 , sheep raising became profitable as well. By the 1880 s, sheep had assumed a dominant role in land use and were exerting an increasing influence (Boyce 1937).

Homesteading didn't figure prominently in the area's development until the 1880 s, after the Northern Pacific was completed. According to settlers interviewed, land could be acquired by first paying an initial fee of $\$ 150.00$ to the government, and then spending at least two nights on the property duning each 6-month period for 3 years. After that time, settlers could pay $\$ 150.00$ more and acquire title to 160 acres.

(a) August Eastland, Histery of Benton and Franklin Counties and Other Interviews, housed at the Washington State Library, Olympia, Washington. 
The railroad encouraged settlement by offering discount tickets to prospective land buyers.

Homesteading on the shrub-steppe was a difficult proposition. Many settlers, financially pressed by the cost of moving to the area, were unable to generate enough capital to make their farms profitable (Yoder 1938). Most of the land in eastern Washington was considered more suitable for grazing than farming (Yoder 1938), as soils are commonly stony at higher elevations and sandy at lower elevations (Hajek 1966), making row cropping difficult. Most importantly, water was a fairly scarce resource. Thus, for most of the lower Columbia Basin, sheep and cattle grazing operations played a far more important role than did homesteading at that time.

The ALE Reserve is fairly typical of a wide range of shrub-steppe habitats, because it is situated on the northeast-facing flank of the Rattlesnake Hills.

Rattlesnake Mountain is a long anticlinal ridge with a crest at $1100 \mathrm{~m}$ mean sea level (MSL) for $5 \mathrm{~km}$; elevations drop to $125 \mathrm{~m}$ on the mountain's southeastern end at the Yakima River. The gently sloping southern side of Rattlesnake Mountain (outside of ALE) currently supports dryland wheat farming at the higher elevations. By contrast, the northern slope drops steeply (about 25 degrees) to $650 \mathrm{~m} \mathrm{MSL}$ elevation, then eases to 7 degrees slope down to about $350 \mathrm{~m}$, and finally slopes gently down into the Cold Creek Valley $(150 \mathrm{~m})$.

Average annual rainfall on the ALE Reserve increases with elevation, and diverse microclimates result form combinations of slope, exposure, and elevation encountered in the uplift (Rotenberry et al. 1976; Thorp and Hinds 1977). Vegetation is characterized by widely distributed shrubs and perennial grasses in addition to a few annual and many perennial herbs.(a) A summary of the major kinds of potential shrub-steppe communities and where they occur on ALE is included in Figure 2.

\section{PRE-SETTLEMENT LAND USE}

Indians in the Columbia Basin lived on reliable food sources such as salmon and camas roots (Camassia quamash), sharing access to major food resources while maintaining stewardship rights. Dispersed summer task groups were complemented

(a) The density of shrub vegetation is currently much reduced as a result of recent humanrelated fires, which burned about $80 \%$ of ALE in 1981 . 


\section{PLANT COMMUNITIES OF THE ALE RESERVE}

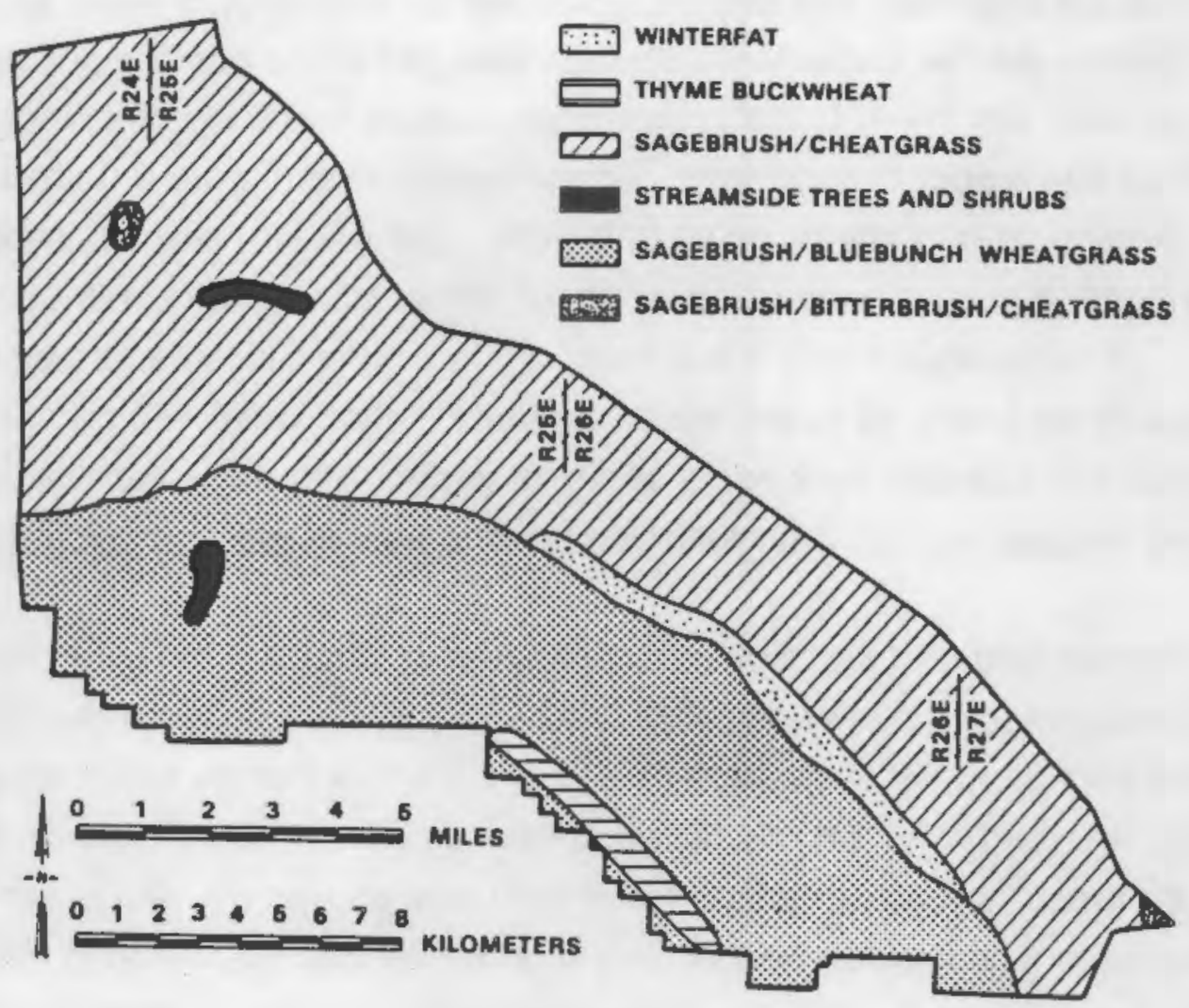

FIGURE 2. Plant Communities of the ALE Reserve

by winter villages and special gatherings (Knudson 1980). The ALE Reserve was on the pathway used by migrating Indians, who traveled across the shrub-steppe to reach wet meadows supporting their winter staple, camas roots. Former residents of the ALE Reserve recalled social interactions with these bands of migrating Indians as late as 1930. Indian trails were known by settlers, who apparently used them routinely.

\section{HOMESTEADING}

Homesteading on ALE began sometime in the 1890s. Settlers built homes with whatever wood they could get and raised hogs, horses, a few cattle, and sheep. Although all early settlers planted a garden, most efforts at dryland farming ended in failure. Homesteads relying solely on rainfall were without adequate water and were abandoned before the end of the 1920s. Homesteads that succeeded on ALE depended on grazing or sheep raising activities. 
The life of settlers was difficult, governed by limitations of water and soil. Water as a limitation may be immediately obvious now, but it was not to many early, and naive, settlers. On the ALE site in particular, location made the difference between a successful and a poor dryland farm. Upper Snively field (Figure 2), at about $530 \mathrm{~m}$ MSL elevation, apparently received only $20 \%$ more $(25 \mathrm{~cm})$ annual precipitation than did the Porter-Hartman homestead, at about $330 \mathrm{~m} \mathrm{MSL}(21 \mathrm{~cm}$; see Thorp and Hinds 1977). The two sites are only a few miles apart, yet the Snively's farmed their land successfully for nearly $\mathbf{4 0}$ years, while residents of the Porter-Hartman homestead were forced to abandon their home within 15 years. Both sites apparently supported the same vegetation, big sagebrush and bunchgrass (Agropyron spicatum).

Snively field was first plowed and planted to a mixture of wheat, rye, and barley in 1906, according to homesteader Frank Bennett. No irrigation was used, and the crop was kept as winter livestock feed. In areas where nearby water supplies made irrigation feasible (lower Snively field and Benson Ranch; see Figure 3), alfalfa was raised for livestock feed. Irrigation water from springs was plentiful in some areas on ALE, particularly at Benson Ranch. Irrigation for Benson originated at Rattlesnake Springs; it was piped 3 miles, then traversed the last 2 miles in an open ditch. Former residents of Benson Ranch indicated that this spring-fed irrigation supplied all of their water needs. The only time they had difficulties with water was in the spring, when trailing sheep caused trampled vegetation to clog the system.

One other activity of homesteaders is noteworthy. Finding water scarce in most places, homesteaders used every means available to provide winter livestock forage. This included haymaking with native bunchgrasses (Figure 4). Early residents still believe bunchgrass was "more abundant" (more productive) during the homesteading era than it is currently. Average bunchgrass production is now about $40 \mathrm{~g}$ per square meter per year or about $400 \mathrm{lbs}$ per acre (Rickard et al. 1976). The wide spacing of what is presumed to be hay shocks in Figure 4 does not provide strong support for the settlers' remembrances.

Patterns in plant succession resulting from homesteading activities raise some intriguing questions. At Porter-Hartman, succession in greatly disturbed (plowed) areas appears to be simple and predictable: cheatgrass predominates. At lower elevations and in areas where irrigation was practiced, dominance patterns vary. Cheatgrass, Jim Hill mustard, jagged chickweed (Holosteum umbellatum), and stork's 


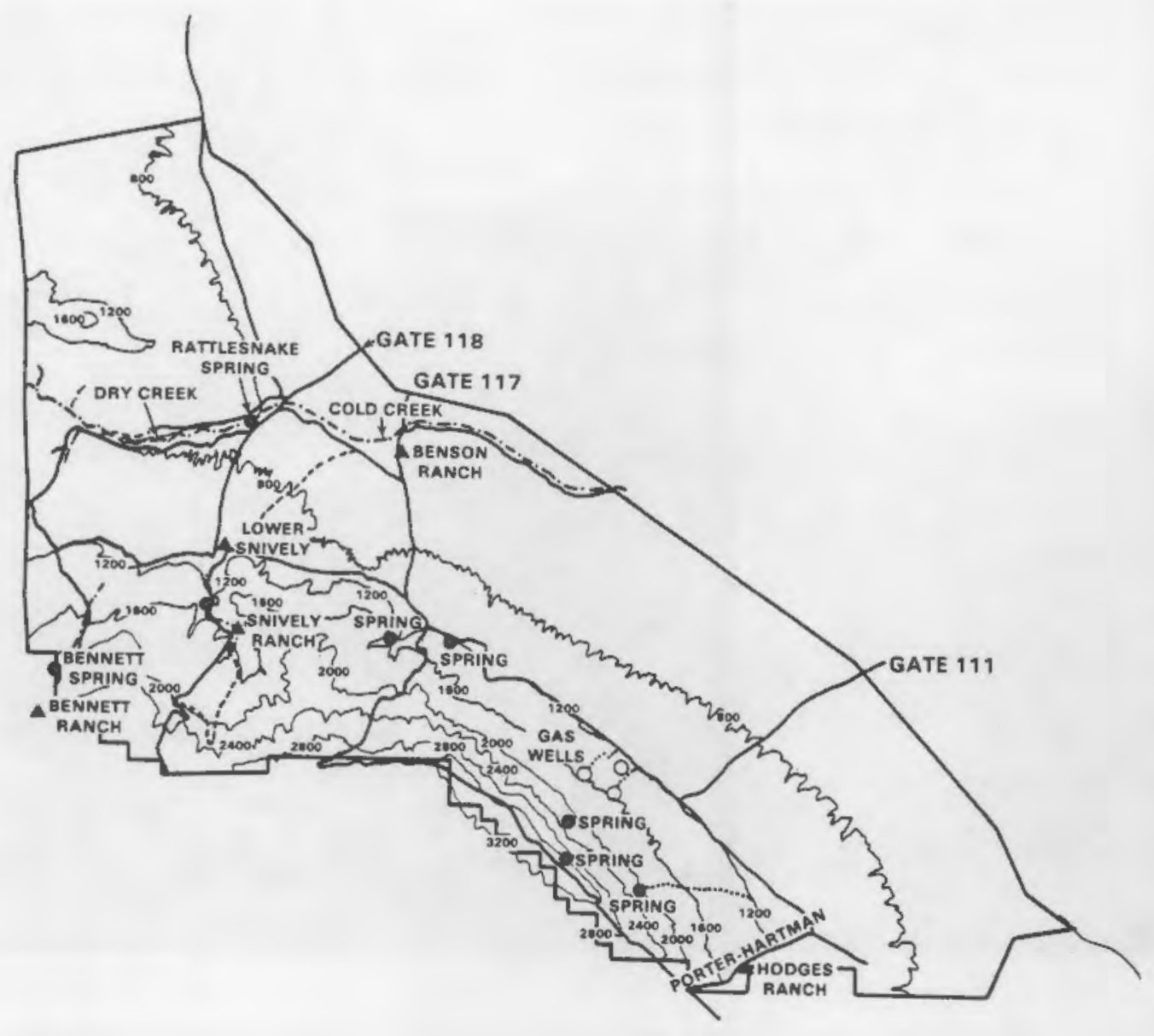

FIGURE 3. Settlement on the ALE Reserve

bill (Erodium cicutarium) assume varying degrees of importance from year to year. At upper Snively, cheatgrass remains important, but another invading plant has become codominant in the last 10 years. Black rye (Secale cereale), present in small populations at Snively since dryland farming was abandoned, has expanded its territory to include much of the old field. Mechanisms underlying this massive population expansion are not yet understood.

\section{GRAZING}

The ALE Reserve served as an important winter grazing range for sheep from the mid-1880s through the 1940s. The area was well suited for winter grazing because of its relatively mild winter weather; the northeastern slope of Rattlesnake Mountain in particular was suitable for winter grazing because of the availability of winterfat (Eurotia lanata), a highly desirable forage shrub. The nearest alternative 


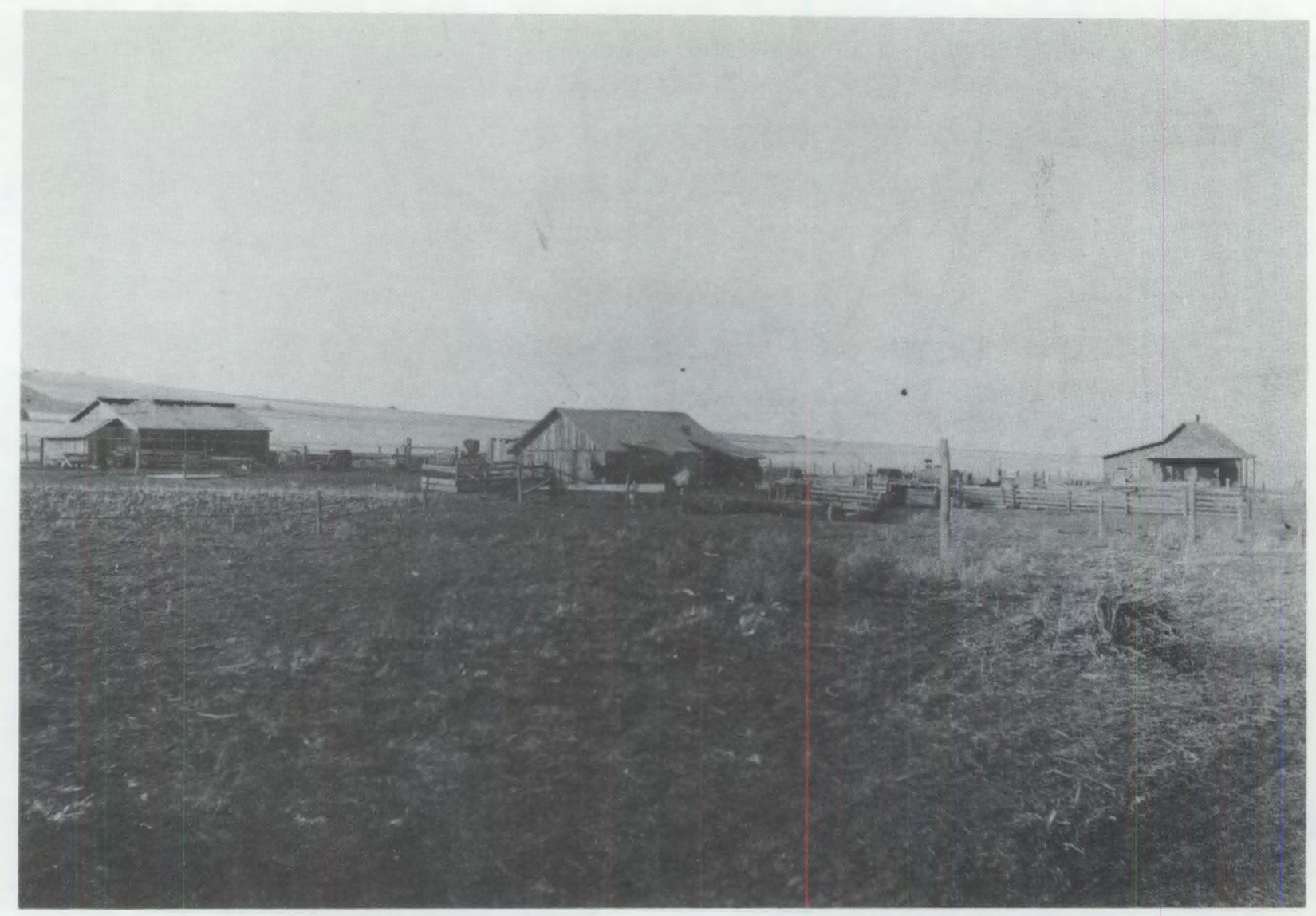

ElGURE4. Porter-Hartman Homestead Circa 1906. Arrows denote possible bales of bunchgrass.

winterfat location was Wahluke slope, some $\mathbf{3 0}$ miles away and across the (then unbridged) Columbia River.

Eventually, the sheep industry declined because of increasing settlement and its attendant fencing practices, which eliminated the large open range necessary to accommodate these animals. Sheep ranchers eventually turned to other forms of employment--raising cattle, wheat farming, or working for area businesses.

Several former sheep ranchers estimated that 9000 to 15,000 sheep wintergrazed on ALE annually between 1880 and 1940. "Territories" of sheep ranchers using ALE on a regular basis can be identified or mapped and covered about $80 \%$ of the land area (Figure 5). However, these territories and the winter grazing estimates do not take trailing bands into account, which may have exerted considerable shortterm pressure on the land at a time when seedling growth was at a maximum (spring). 
Winter grazing on ALE was restricted to the months of November through January. Lambing took place early in February, followed by shearing (McWhorter 1943). Because they owned property in locations where water was more plentiful, regular users of the winter range on ALE did not lamb or shear on ALE, though sheep herders without winter range rights annually trailed through the Reserve for February lambing and shearing at Benson Ranch. Residents of Benson Ranch were share croppers, making their living by growing alfalfa for sheep feed and working as assistants to sheep men during lambing and shearing. The Bronkhorst family, for example (residents of Benson from 1927 to 1937), indicated that they assisted in lambing and shearing operations for eight to ten bands of sheep annually.(a)

Once lambing and shearing were complete, sheep were trailed or transported by rail to a summer grazing range, usually in the Cascade or Bitterroot mountains. Sheep returned to the Yakima Valley for breeding during the fall months (McWhorter 1943) and were brought to winter range again in November, completing an annual cycle.

Water severely restricted grazing and resulted in overuse of some areas. Lack of surface water was a problem, especially on the best grazing territory. Virgil McWhorter constructed about five cement cisterns throughout his grazing ternitory and had water brought in from the Columbia River to fill them. Other grazers were less affected by a shortage of water, using irrigation troughs, springs, or streams.

Land use practices distinctive to sheep grazing included the "railing" of sagebrush, penning of sheep, winter grazing, and some spring grazing. Sheep men preferred winter grazing lands that were low in sagebrush and high in bunchgrass. Sheep would eat bunchgrass and foraged little from sagebrush; moreover, dense stands of sage tended to cause pulls and breaks, diminishing the wool's value. Sheep men said that they often "railed off" sagebrush to encourage the spread and growth of bunchgrass. Railing is particularly evident at one location on ALE where sagebrush was removed methodically, leaving a large, square plot that is now dominated by cheatgrass. Sagebrush has begun to invade this areas, but comparisons of successional rates with other areas (such as the persistently cultivated Snively fields) have yet to be made.

(a) A band of sheep is 1200 to 1500 ewes and lambs, according to former sheep herders. 
GRAZING \& SHEEP RAISING ON RATTLESNAKE MT.

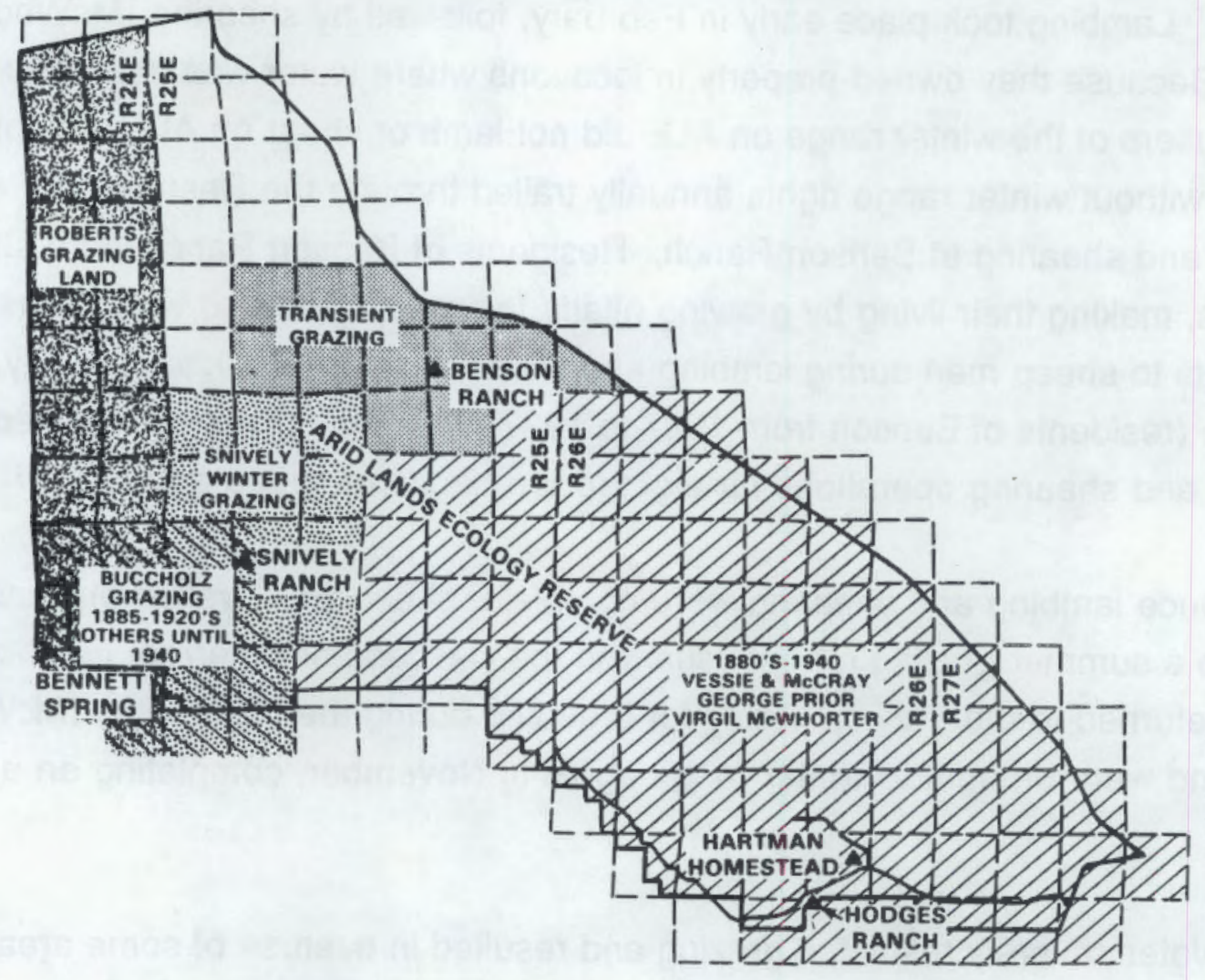

FIGURE 5. Grazing Territories on ALE 1880-1940

Sheep were penned mostly in conjunction with lambing and shearing activities. Old pens on ALE can still be identified, and in some of these, erosion has been so great that recolonization has been prevented, even by non-native species. For the most part, however, alien weeds readily invaded the sandy soils at lower elevations in particular, even when disturbances were relatively minor.

Interviews corroborate this observation: several sheep ranchers recalled the advent of cheatgrass around 1910 to 1913 with relief, noting that its stabilization of old sand dunes helped to lessen the effects of annual spring dust storms. Old sheep pens at higher elevations are consistently dominated by cheatgrass.

Winter grazing activities can be identified in places on ALE by characteristic trail patterns left on steep hillsides (see Stoddart and Smith 1975). Such trials are widely 
evident throughout most of the Walla Walla and Yakima river drainages, and much of the arid portion of the Columbia River drainage. Former sheep grazers were asked how many sheep could be grazed on shrub-steppe land and whether they thought ALE had been lightly, moderately, or heavily grazed. Their estimate for appropriate grazing ranged from 120 to 125 acres for one cow or five sheep; most of them believed ALE was moderately grazed.

As indicated earlier, some spring grazing occurred on ALE in conjunction with lambing, shearing, and subsequent trailing activities. Interviews revealed that most spring grazing was restricted to the lower elevation of ALE in the Cold Creek Valley. Reconnaissance showed more evidence of sheep on this part of the Reserve than on the hillsides where winter grazing alone occurred. Research to document present-day recovery can be expected to shed light on the relationships between recovery and

- extending grazing use into spring, a time of most active growth for shrub-steppe plants

- penning sheep during early spring

- soil erodibility. Most erosion of sandy soils in lower elevations is by wind in the spring (Hinds and Sauer 1973); soils at upper elevations tend to erode more by water from melting Chinook winds in later winter.

\section{QIL/GAS PRODUCTION}

Natural gas was discovered on ALE in 1913, when the Conservative Land Investment Company of Spokane drilled for water on the site and encountered gas at $705 \mathrm{ft}$. Flow was estimated at 70,000 to 500,000 cubic feet per day at 5-1/2 to 7 pounds per square inch (psi) pressure. The gas field (southwest quarter of T11N, R26E) was not actually developed for commercial use until 1929 (Figure 6). At that time, gas escape to the atmosphere had lowered the pressure to $2 \mathrm{psi}$. During maximum production, 16 wells from 700 to $1200 \mathrm{ft}$ in depth produced natural gas for the communities of Toppenish, Prosser, Grandview, Sunnyside, Satus, Granger, and Mabton (McFarland 1978). Nearly 1.3 billion cubic feet of gas was extracted from 1929 to 1941, when production ceased. According to a former employee of the gas field operations, most of the gas had been removed when production ceased. Company geologists felt the gas had formed as limited pockets in volcanic deposits.

Seven families lived in the vicinity of the gas field during the operational period and acted as caretakers of the facility. Relics in the form of foundations, pipes, and 


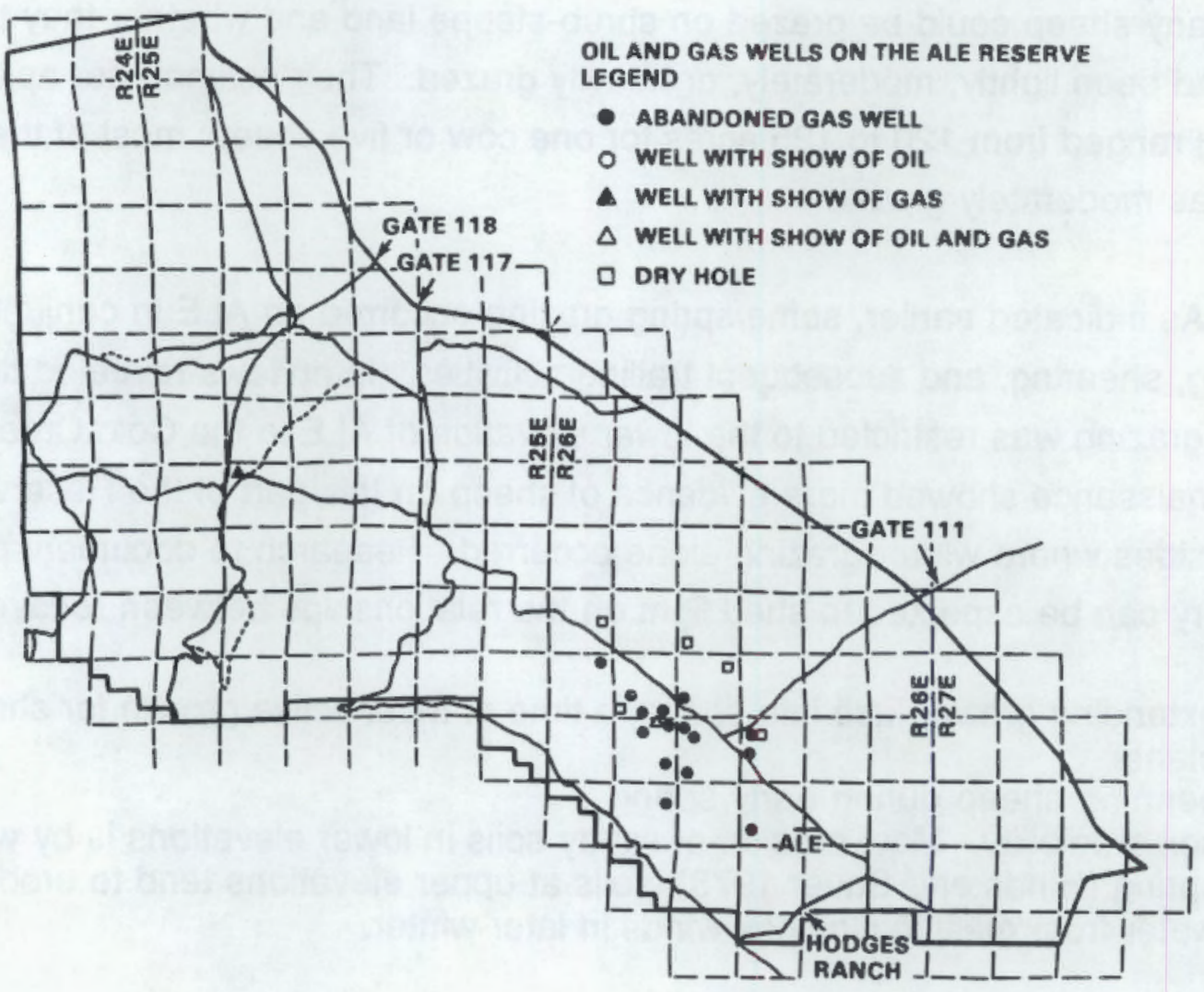

FIGURE 6. Development of Gas Field on the ALE Reserve, 1929-1941

assorted garbage betray evidence of this relatively recent habitation. Although few relic plants remain, photos taken during gas field operation reveal prolific flower gardens and trees.

\section{ROAD BUILDING}

Early accounts of the Columbia Basin/Yakima Basin suggest the existence of a well-traveled trail across what is now ALE near Benson Ranch and toward Rattlesnake Springs. Brown (1969) indicates several reasons this would have been a favored route of travelers. The grade is failly gentle, game and water were abundant, and pasturage near water was better than average compared with the rest of the Rattlesnake Hills. 
The roads built in the early 1900 s (roads are clearly indicated on a 1917 U.S. Geological Survey topographic map) on ALE, and surviving in part today, may approximate early routes. Because ALE has been closed to the general public since the 1940s, only limited road-building has occurred since that time with the exception of firebreak construction and the Bobcat Canyon Road (Figure 3), built by V. $O$. McWhorter about 1936. Remains of roads not maintained after 1967 can be readily discemed. In many cases, these roads have now been colonized by sagebrush. 



\section{CONCLUSIONS AND DISCUSSION}

The major land uses of ALE from the late 1800s through 1940 were winter sheep grazing, homesteading, gas drilling and production, and road building (Table 1).

Winter sheep grazing was the most prominent use of the land for profit. A total of 9000 to 15,000 sheep were grazed annually during November, December, and January. Some spring grazing and penning in conjunction with lambing and shearing took place at the lower elevations near Benson Ranch. Feed plants for sheep included winterfat, species of bluegrass and wheatgrass, and cheatgrass. Land use practices associated with grazing included railing sagebrush and supplementing water supplies with cisterns or irrigation troughs. Succession in these areas is characterized by non-native plants, particularly cheatgrass.

Iable 1. A Summary of Land Use Practices Employed on the ALE Reserve, 1890-1940

Land Use

Homesteading

Winter/spring sheep grazing

Practice Emploved
building, dryland farming
irrigation
Haymaking with bunchgrass
Grazing control, construction
of sheep watering areas
Penning areas
"Railing" sagebrush

Winter grazing

Building, pipe maintenance

Road building
Road construction and offroad travel
Visible Indications on ALE

Presence of foundations; relic stands of rye; ditches; large stands of introduced plant species

None

Drift fences, identifiable water troughs

Identifiable "pens" dominated by cheatgrass or tumble mustard

Square plots where shrubs are absent or infrequent

Horizontal trail lines, especially on steeper slopes

Old pipelines; presence of relic plants or artifacts; old wells

Identifiable roads or trails; presence of cheatgrass in tracks 
Homesteading was practiced from about 1890 to 1940 . Only a few farming homesteads situated near a reliable source of water remained for many years. Homesteaders raised sheep, cattle, and hogs and practiced some dryland farming for feed purposes. Bunchgrass was sometimes cut into hay and used for feed as well. At Benson Ranch, where water was abundant, alfalfa was raised. Succession in homesteaded areas depended on the availability of water. Formerly irnigated areas often support large populations of Jim Hill mustard, chickweed, and stork's bill in addition to cheatgrass. At Snively Ranch, black rye has assumed a greater degree of dominance within the last 10 years.

Water severely restricted grazing and resulted in overuse of some areas. Lack of surface water was a problem, especially on the best grazing ternitory. Virgil McWhorter constructed about five cement cisterns throughout his grazing territory and had water brought in from the Columbia River to fill them. Other grazers were less affected by a shortage of water, using irrigation troughs, springs, or streams.

In 1913, a well dug on ALE revealed the presence of natural gas. Full-scale operation of the gas field began in 1929 and ended in 1940. Twenty-four wells were dug with the main gas field located in the southwest quarter of TWP $11 \mathrm{~N}, \mathrm{R} 26 \mathrm{E}$. Roads were identifiable on ALE before homesteading began. A well-used Indian trail runs across Benson Ranch to Rattlesnake Springs; the current road probably follows this old trail somewhat.

Research conducted on ALE since the late 1960s sheds some light on the climatic, edaphic, and ecological factors that determine the susceptibility of shrubsteppe lands to disturbance. Recovery rates appear to depend on the susceptibility of a given soil to erosion (either wind or water) as much as frequency or type of land use. New questions have aiso been raised by the knowledge gained in this effort. In particular, comparisons of successional rates on ecologically disparate sites may provide insights into how recovery of shrub-steppe lands may be predicted. 


\section{BEFEBENCES}

Boyce, T. V. 1937. A History of the Beef Cattle Industry in the Inland Empire. M.S. Thesis, State College of Washington, Puliman, Washington.

Brown, R. E. 1969. Interrelationships of Geologic Formations and Processes Affecting Ecology as Exposed at Rattlesnake Springs Hanford Project. Arid Land Ecology Program Preprint Series No. 3. BNWL-B-29. Pacific Northwest Laboratory, Richland, Washington.

Hajek, B. F. 1966. Soil Survey Hanford Project in Benton County. Washington. BNWL-243, Pacific Northwest Laboratory, Richland, Washington.

Hinds, W. T., and R. H. Sauer. 1975. "Soil Erodibility, Soil Erosion, and Secondary Succession Following Wildfire in a Shrub-Steppe Community." In Symposium on Atmosphere-Surface Exchange of Particulates and Gaseous Pollutants. CONF740921, National Technical Information Service, Springfield, Virginia.

Knudson, R. 1980. "Fish, Roots, Game, and Trade in the Columbia Plateau." $\downarrow$ Foresix 78(9):542-546.

McFarland, C. 1978. Oil and Gas Exploration in Washington 1900-1978. DNR Info. Circular 67, Department of Natural Resources, Olympia, Washington.

McWhorter, R. 1943. "Program for a Livestock Farm." The Cattleman 29(8):77-83.

Meinig, D. W. 1968. The Great Columbia Plain. A Historical Geography 1805-1910. University of Washington Press, Seattle, Washington.

O'Farrell, T. P. 1973. "Project ALE, A Natural Desert Community." Pacific Search. July 1973.

Pacific Northwest Laboratory. 1973. Annual Report for 1972 to the U.S. Atomic Enerax Commission Division of Biomedical and Environmental Research. BNWL1750, Vol. 1, Pt. 2. Pacific Northwest Laboratory, Richland, Washington.

Rickard, W. H., D. W. Uresk, and J. F. Cline. 1976. "Productivity Response to Precipitation by Native and Alien Plant Communities." In Rroceedings of a Symposium on Terrestrial and Aquatic Ecological Studies of the Northwest, p. 1-7. Eastern Washington State College, Cheney, Washington.

Rotenberry, J. T., W. T. Hinds, and J. M. Thorp. 1976. "Microclimatic Pattems on the Arid Lands Ecology Reserve." Northwest Sci. 50:122-130.

Stoddart, L. A., and A. D. Smith. 1975. Bange Management. 2nd ed. McGraw-Hill, New York. 
Thorp, J. M., and W. T. Hinds. 1977. Microclimates of the Arid Lands Ecology Reserve 1968-1975. BNWL-SA-6231. Pacific Northwest Laboratory, Richland, Washington.

Yoder, F. R. 1938. "Pioneer Social Adaptation in the Palouse Country of Eastern Washington, 1970-90." Research Studies of the State College of Washington VI(4):131-159. 


\section{DISTRIBUTION}

No. of

Copies

\section{OEFSITE}

12 DOE Office of Scientific and Technical Information

\section{ONSITE}

9 DOE Richland Operations Office

P. F. X. Dunigan

P. W. Kruger

M. W. Tiernan (5)

DOE Public Document Reading Room (2)

38 Pacific Nonthwest Laboratory

L. L. Cadwell

J. L. Downs

J.W. Falco

R. H. Gray

P.C. Hays

R. E. Jaquish (20)

S. O. Link

G.P. O'Connor

W.H. Rickard

L.E. Rogers

W. L. Templeton

J. M. Thomas

M. E. Thiede

Publishing Coordination

Technical Report Files (5) 
